\title{
Corporate Social Responsibility as a Positioning Strategy: Evidence from the Ghanaian Telecommunication Industry
}

\author{
Nathaniel Newman \\ University of Ghana Business School, Ghana
}

Copyright $\bigcirc 2017$ by authors, all rights reserved. Authors agree that this article remains permanently open access under the terms of the Creative Commons Attribution License 4.0 International License

\begin{abstract}
Purpose - The telecommunication industry in Ghana has seen a lot of growth over the last decade and with up to six telecommunications companies operating in Ghana currently, there is very little to choose between any two brands. In an overly communicated sector such as the telecom sector, CSR as a positioning strategy seems to be a better way to differentiate one's offering from the rest. With customers more concerned about organisations social responsibility activities and with the telecommunications companies investing huge sums of money in to CSR activities it is imperative to find out if the telecom companies employ CSR (image and ethos) as a positioning strategy. Design/methodology/approach - The study used a sample of students from the University of Ghana who are customers of the telecommunication companies. The study adopted a non-probability quantitative survey using questionnaires. Findings - The key findings of the study were that, respondents were of the view that, the network providers were adopting image and ethos as a positioning strategy, only two strategies positioning competition and image and ethos strategy were adopted and the dominant positioning strategy was competition. Research limitations/implications - Future studies be carried out in other jurisdictions to affirm the validity of the results. Also a longitudinal study with respect to the positioning strategies of firms should be carried out to ascertain the changing trends that can impact and affect the positioning strategy of the firm. Originality/value - It is the first of its kind to be carried out in Ghana in the area of CSR as a positioning strategy and will be of interest to academics and practitioners in both CSR and positioning.
\end{abstract}

Keywords Corporate Social Responsibility, Positioning, Strategy, Telecommunication

\section{Introduction}

In recent years attention to issues attendant to corporate social responsibility (CSR), has grown [30, 36, 79, 131]. This, interest for CSR has spread to the marketing literature as well [7]. The interest in CSR could be said to be arising as a result of the many benefits that an organisation can enjoy by engaging in strategic corporate social responsibility activities. As asserted by McDonald and Rundle-Thiele [94], the benefits of corporate social responsibility (CSR) for companies, include increased profits, customer loyalty, trust, positive brand attitude and combating negative publicity $[26,41,88,102,128,129]$. Additionally, this interest in CSR may also be due to the sanctions and pressures that organisations face from government and host communities for being socially irresponsible. According to Porter and Kramer [116], "governments, activists and the media have become adept at holding companies to account for the social consequences of their activities" [116 p. 1].

Additionally, Ofori and Hinson [107] state that, the field of corporate social responsibility has seen considerable growth over the last decade and that "stakeholder demands on businesses have increased at such a dramatic rate that, given the immensity of these pressures, large and small firms find it increasingly difficult to avoid assuming their corporate social responsibility (CSR)" [107 p. 178].

There is also evidence to suggest that firms may benefit from socially responsible actions in terms of improved employee morale and productivity $[100,111,132]$. The benefits of CSR to an organisation may also include positive organisational and brand reputation. It is perhaps to reap some of these benefits that, telecom operators in Ghana invest considerable sums of money into high-impact CSR activities, mostly in the area of education, health, environment, sports, music, arts and entertainment as noted by Ofori and Hinson [107]. 
The issue of telecommunications firms in Ghana having an overt CSR focus was also touched upon by Hinson and Kodua [63], when they asserted that, the firm that won the "Ghana Club 100 Best Company in CSR" during the 2009 edition of the annual awards scheme was a telecommunication company operating in Africa and the Middle East. The authors also stated that, the mission statement of the company which won the award was: “building shareholders' value by ensuring maximum customer satisfaction through providing latest telecommunication services, at the most economical rates while meeting its social responsibilities as a good corporate citizen and providing growth prospects for its employees" [63 p. 335].

This brings to fore the idea that CSR practices of a firm could have a bearing on the positioning of that firm's products and services in the minds of current and potential consumers. Du et al. [42], explain that, the need to understand the unexamined role of CSR positioning in consumer reactions to a company's CSR actions is emphasized by the unique nature of such a positioning strategy compared to those along more traditional dimensions such as operational excellence, product innovativeness, or customer intimacy. This is because it is "a company's actions in the CSR domain, as opposed to other, more product-related ones, that truly reveal its "values" [137], "soul" [36], or "character" [26]; comprising the company's identity Bhattacharya and Sen [17 p. 225].

From a positioning point of view, Blankson and Kalafatis [22] assert that, there is a general agreement in the positioning literature which suggests that, positioning is an essential element of marketing strategy and that just like service, it has no generally accepted definition. Explaining further, the authors assert that, the absence of a generally accepted definition may be due to the non-existence of a clear theoretical basis for positioning [123] and the straightforwardness given to the meaning of positioning. According to the authors, this development has given rise to different terms associated with the concept (i.e. positioning, position, product positioning, market positioning etc.) but as stated by Arnott [10], the different terminologies are simply "several sides of the same coin" and complement each other. Further, Blankson and Kalafatis [22] added that, the different terminologies and viewpoints of positioning can be grouped under three underlying issues: conceptual, operational, and strategic. This study therefore focuses on investigating the use of corporate social responsibility (CSR) as a positioning strategy within the context of an emerging economy telecommunication industry.

From a general perspective, the discussions of CSR as a positioning strategy has not been examined beyond Blankson's [20] assertions of an extension to the generic positioning strategies propounded by Hooley and Saunders [66], Hooley et al., [67] which were following from discussions by Aaker and Shansby [1] of these positioning strategies. The study was on bank cards and was conducted in a developed country.

In an earlier study, Lopez and Boluda [81] tabulated social reputation and esteem as one of three general positioning strategies. Explaining the strategy, Lopez and Boluda [81] assert that, the social reputation and esteem strategy defines the product in terms of general consumer requirements citing [85, 11]. Adding that, in such an instance an appeal is made to the concern for the environment or the rejection of political corruption. Stressing that, the approach offers contingent social benefits and positive image for the supplier and the product supplied. The paper was looking at the generality of a number of positioning alternatives and not necessarily social reputation and esteem as a positioning strategy or a survey against other positioning strategies.

In the Maggard [85] paper, the author was simply revisiting thoughts about positioning as an emerging trend in marketing. Maggard [85] used the term positioning for social accountability. Asserting that, manufactures of consumer products must be well informed about the movement toward consumer protection, a development which the author assert that, will definitely continue into the future. Adding that, taking a social accountability stance is one to be coveted in today's market. Concluding that, a lot of organizations through their promotional planning are trying hard to project the image of good citizenship. As mentioned earlier, the paper was not conducting a survey in to positioning strategies or even social accountability as a positioning strategy. Further checks through literature shows that few studies have been conducted on CSR and positioning [7, 42].

Blankson and Kalafatis [23] asserted that over the years, much has been written in the area of service positioning see for example, [8, 9, 10, 11, 37, 43, 49, 70, 72, 82, 148]. However, due to the special nature of services compared to physical goods, not only are services difficult for consumers to compare with competing services [Donnelly et al., [40] cited in Walker et al., 141] but they pose challenges in their positioning $[49,149,18]$ by marketing managers. The authors further stated that, some reporters have claimed that despite the inherent differences between physical goods and services [149, 18], there are overlaps between services and physical goods [14, 80, 99] "which means that there is no compelling reason to adopt different positioning strategies in services see, [147, 28]" Blankson and Kalafatis [23 p. 236).

Against this background, and also on the basis of observations by Mahmoud and Hinson [78] that, a firm in the service sector, such as the telecommunication industry, can hardly differentiate itself on the basis of the products or services making it extremely difficult for achieving competitive advantage base on product-only strategies. This study is therefore positioned to fill the gap in literature on insights into CSR and positioning research in 
developing economies; and develop an understanding from customers in a less developed country on CSR as a positioning strategy of telecom companies in Ghana.

The objectives of this study is to shed light on the concept of CSR as a positioning strategy based on views from customers of telecommunication companies. Specific objectives are; to examine if the telecom companies in Ghana have employed CSR (image and ethos) as a positioning strategy; to examine the different positioning strategies employed by the telecom companies in Ghana; to examine the dominant positioning strategies employed by the telecom companies in Ghana.

\section{Literature Review}

\section{Origin of Positioning}

Blankson [19] assert that, the source of the term positioning is unclear [4] but explain that, Nylen [105] stated that positioning dates back to the 1940's from studying marketing mix. The term is seen as relatively new $[122,134,75]$ and emanated from market segmentation, targeting and market structure changes during the 1960's and the early 1970's [103, 127]. Ries and Trout [121] cited in Smith and Lusch [130] suggest that positioning is rooted in the packaged goods field where the concept was termed product positioning. For Arnott [10] positioning may have emerged from measurement of consumer perceptions and "perceptual mappings" studies. Considering the different opinions about the origin of positioning, it not surprising that its definition also has several sides to it.

\section{Definitions of Positioning}

According to Blankson [19], there isn't a generally accepted definition for positioning and that it could be attributed to the absence of a clear theoretical stance on the concept [123]. The author also added that, there is a general agreement in the literature suggesting that, positioning is a fundamental element of marketing strategy although it can be looked at from a conceptual, practical or strategic point of view.

Arnott [8] assert that, the term positioning is the deliberate proactive, iterative process of defining, measuring, modifying and monitoring consumer perceptions of a marketable object. According to Blankson [20], this definition includes both strategic and applied perspectives of positioning.

For Ries and Trout [122], positioning is not what is done to the product or service, but rather what is done to the mind of the prospect (i.e. potential buyer) and went on to state that fundamentally, the essence is to position the offering in the mind of the consumer, and that, "positioning shifts the emphasis of marketing from the product to the battle for your mind" cited in [20 p. 1].
Kotler [75] also defines positioning as the process of designing the company's product or services and image based on consumers' perceptions relative to that of competitors. Hassan and Craft [59] also assert that, the term "positioning" is "often used to refer to the firm's decision to determine the place that its brand and corporate image occupy in a given market including the type of benefits to be stressed and the type of segments to be targeted" [59 p. 345].

\section{Schools of Thought}

According to Blankson [19], there are two schools of thought on the concept of positioning citing Muhlbacher et al. [101]. He explain that, the authors assert that the first school of thought sees positioning as either embedded within the framework of issues concerned with the marketing mix or associated with strategic decision making. Explaining further, Muhlbacher et al. [101] contend that, proponents of the first school of thought associate positioning largely with the communication elements of the marketing mix. To them, positioning is seen as a powerful tool in "competitive warfare" see $[121,122,136$, $135,134]$.

The second school of thought according to Muhlbacher et al. [101] sees positioning as an aggressive strategy of adjusting customer beliefs about the benefits and qualities of a product or service. The authors explain that, adherents of this school of thought associate positioning with product policy with respect to the selection of particular product features to develop or to emphasise see $[127,112]$, quoted in [54].

\section{Conceptualizing Positioning}

Blankson and Kalafatis [23 p.79], explain that, review of literature shows an increasing attention and activities associated with the concept of positioning citing $[1,3,34$, $38,65,113,120]$ and that the subject is seen as one of the important features of modern marketing management [67, $76,114]$ and the basis for formulating marketing communications plans [48, 122, 124]. Blankson et al. [20] also assert that, positioning is conceptualized as a complex multidimensional construct that attempts to positively adjust the tangible characteristics of the offering and the intangible perceptions of the offering in the marketplace [20 p. 107].

According to Arnott [8], the usage of positioning strategies includes some related activities such as defining the dimensions of a particular perceptual space that sufficiently characterizes the target audience's perceptions; measuring objects locations within that space and changing actual characteristics of the object and perceptions of the target audience through marketing communications strategies cited in Blankson and Kalafatis [23].

Blankson [19] also assert that, review of the extant literature points to only two formally expressed 
strategically based conceptual positioning frameworks. The Brand Concept Image Management (BCM) model by Park et al. [110] and the Generic Positioning Framework (GPF) propounded by Hooley and Saunders [66] and revisited by Hooley et al., [67].

\section{Generic Positioning Model}

According to Blankson [20], Hooley and Saunders [66] assert that a firm can position itself on the basis of four key generic positions: (consolidation, latent position, deposition, and membership). For each position, the firm can follow six different positioning strategies namely (attributes, price/quality, competition, application, user, and product class). Within a particular position, there are explicit marketing communication tactics and other promotional efforts used to project the offerings' positioning to a targeted market.

\section{Extension to Positioning Strategies}

Blankson [20] assert that, a seventh strategy called organisational "image/ethos" is proposed and added to the positioning strategies. The author explain that as a result of the growing importance associated with the improvement in better corporate image [16], and the increase in company affinity to humanitarian, sympathetic and environmental friendly causes [146], and the growing consumer awareness about "cause-related marketing" [33], several organisations are trying very hard to differentiate themselves along the lines of good external image, ethos and good citizenry $[92,56,33,133]$. This is how Blankson [19 p. 557-559] explain the six positioning strategies:

Attributes: This positioning strategy relates to distinctiveness or similarity to other products/services. It is used to create awareness among a targeted segment and could involve the promotion of certain specific features that competitors have ignored.

Price/Quality: This strategy is used as the basis for a firm's dominant position in the market place, price and quality may be considered separately depending on the particular product or service.

Competition: Competition involves aggressive tactics and is aimed at overtaking competitors.

Application: In application, consumers are informed of the best use of the service/product, which is better than that of competitors. The emphasis is on the flexible usage (several use) of the product/service. Citing Aaker and Shanby [1] the author explains that, often application position strategy represents a second or third strategy designed to expand the market.

User: Citing Hooley and Saunders [66], in user, the strategy is to use the recommendation by a dignitary, a popular person or a "star" in the promotion of the firm's product/service.

Product class: Products class is based on differentiation whereby the main thrust of the strategy is either to reposition on new competitive advantages or emphasise its uniqueness from competitors. According to Blankson [19], the authors write that with this strategy, promotional tactics is concerned with moving upmarket or one, which is in the "same league" as other upmarket products/services.

Image and ethos: It is associated with the improvement in better corporate image [16], and to build the image of the organisation along humanitarian, sympathetic and environmental friendly issues and to differentiate the organisation on grounds of good external image, ethos and good citizenry [92, 56, 33, 133].

\section{Background to Corporate Social Responsibility (CSR)}

Over the last decade, the number of companies with socially responsible programmes have increased considerably [131] making it seem as if corporate social responsibility has only now been discovered. However, Asongu [13] assert that, "as early as the 1920s, discussions about the social responsibilities of business had evolved into what could be recognized as the beginnings of the "modern" CSR initiative" (p. 30). Maignan [89] explain that, Bowen [25] is credited for being the first scholar to write on corporate responsibilities. Claiming that, this initial publication heralded countless number of literature on the nature of corporate social responsibilities $[2,35,44$, 93, 95].

Currently, Corporate Social Responsibility (CSR) has become an important topic for economy and research [74, 91, 98]. According to Hinson and Ndhlovu [61], corporations have evolved from the old thinking that they exist solely for the purpose of profit making to the new model that they, as entities shoulder certain responsibilities that go beyond corporate profit maximisation. Chahal and Sharma [31] also assert that, CSR is now an obligation of firms and in some instance has become a "license to operate" [125]. Asongu [12] also explain that, debate about the concept range from those who see it as irrelevant for business [50], to those who see the relevance, but think it is a bad idea for business [52] and others who see it as strategic for business [51].

\section{Definitions of Corporate Social Responsibility}

The first definition of CSR was given by Bowen [25]. The author assert that, CSR is the "obligations of businessmen to pursue those policies, to make those decisions, or to follow those lines of action which are desirable in terms of the objectives and values of our society" (p.6). After this initial definition, several 
individual and organisations have also given their own definitions and interpretations to the concept.

Corporate Social Responsibility (CSR) has also been defined "as a stakeholder oriented concept that extends beyond the organization's boundaries and is driven by an ethical understanding of the organization's responsibility for the impact of its business activities, thus, seeking in return society's acceptance of the legitimacy of the organization" Maon et al. [90 p.72]. This definition, according to the authors is based on the stakeholder concept and calls for the fusion of CSR into organizational strategy. In addition, it states that CSR benefits both the corporation and its various stakeholder groups.

The World Business Council for Sustainable Development [143] defines CSR as "the continuing commitment by business to behave ethically and contribute to economic development while improving the quality of life of the workforce and their families as well as the local community and society at large" cited in Ofori and Hinson [107 p. 181].

McWilliams and Siegel [97] also describes CSR as actions that appear to further some social good beyond the interest of the firm and which are required by law. There are several other definitions as well.

\section{CSR in Developing Countries}

The term developing countries is widely used to describe nations that have relatively lower per capita incomes and are relatively less industrialized [140]. Thus, the researcher's choice of the term developing countries is consistent with the United Nations Developments Program's [138] categorization in its summary statistics on human development. With this in mind, the researcher highlights some of the researches conducted on the concept in developing countries.

According to Visser [140], Asia is the region most often covered in the literature on CSR in developing countries, with a significant focus on China and cited [150]), India [15], Indonesia [24], Malaysia [151], Pakistan [84], and Thailand [73]. Other countries that have had less attention include Bangladesh [104], the Pacific Forum Islands [117], Sri Lanka [83], and Vietnam [119].

Additionally, in Africa, the literature on CSR is dominated by South Africa [139], with other few researches in Côte D'Ivoire [126], Kenya [39], Nigeria [6], Tanzania [45], and Mali and Zambia [58]. CSR research in the Ghanaian context have included studies by Ofori and Hinson [107], Hinson et al., [64], Hinson and Kodua [63], Hinson [62], Kuada and Hinson [78] and Mahmoud and Hinson [87]. In spite of the growing number of studies, Kuada and Hinson [78] intimated that, carrying out their study in Ghana, would contributes to the scarce knowledge of CSR activities in Africa.

\section{Justification for CSR}

According to Ofori and Hinson [107] several themes have formed the justification for broader corporate social responsibility and assert that there do four justifications for organisations want to engage in corporate social responsibility activities. The authors explain that managers have been entrusted with organisational power and that the fate of all stakeholders lies with them. This power, they claim is a duty to improve the welfare of society and meet the needs of other stakeholders. Another reason the authors allude to is that, managers believe that they are oblige to balance the interests of all the various stakeholder groups and that, they act as coordinators who reconcile the different interests of the various stakeholder groups. A third justification the authors give is that, managers agree that society must be served by organisations and finally, the growing concern in most countries with respect to corporate social responsibility activities.

Bowen [25] also lists a number of justifications for CSR which was described by Ofori and Hinson [107] as "an excellent encapsulation of a modern justification for CSR" [107 p.182]. The author state that, "managers have an ethical duty to consider the broad social impacts of business decisions, businesses are reservoirs of skill and energy for improving civic life, corporations must use power in keeping with a broad social contract or lose their legitimacy, it is in the enlightened self-interest of business to improve society, and finally, voluntary action may head off negative public attitudes and undesirable regulations" as cited in Ofori and Hinson [107 p. 182].

\section{Conceptualization of Corporate Social Responsibility}

In their paper corporate social responsibility theories: mapping the territory, Garriga and Mele [53], laid out several theories that underpin CSR. The paper tried to argue for and against the various theories as captured in the literature. They argued that, there are several classifications based on the view points of the managers of the organisation engaged in the CSR activity and that some classifications have been proposed based on subjects related to CSR, such as Issues Management $[142,144]$ or the concept of Corporate Citizenship [5]. Further stating that, alternative views held by Brummer [27] suggests a classification of CSR into four groups of theories based on six different criteria that include motive, relation to profits, group affected by decisions, type of act, type of effect and expressed or ideal interest.

Garriga and Mele [53] also intimated that, although the contributions of the various classifications were vital to the discussion of CSR, they were limited in scope and that the views held by the various theorists were as a result of their understanding of the relationship between business and society $[71,96,118,145]$.

Another profound argument made for CSR is the thought shared by Porter and Kramer [115] who viewed CSR from the concept of shared value. They described shared value as policies and operating practices that enhance the 
competitiveness of a company while simultaneously advancing the economic and social conditions in the communities in which it operates. Stressing that, shared value creation focuses on identifying and expanding the connections between societal and economic progress [115]. The duo further argued that, companies can create economic value by creating societal values. And added that, there are three distinct ways of doing it. The first is by reconceiving products and markets, then redefining productivity in the value chain, and finally building supportive industry clusters at the company's location [115]. According to the two scholars, each of these is part of the virtuous circle of shared value; improving value in one area gives rise to opportunities in the others.

Porter and Kramer [115] the concept of shared value resets the boundaries of capitalism. By better connecting companies' success with societal improvement, it opens up many ways to serve new needs, again efficiency, create differentiation, and expand market. The pair also asserted that, the ability to create shared value applies equally to advanced economies and developing countries, though the specific opportunities will differ.

According to Jamali and Mirshak [69], one of the conceptualizations of CSR which is "well grounded in literature" [69 p. 246] is Carroll's [29] four-part definition of CSR which was embedded into a conceptual model of corporate social performance (CSP). For the purposes of this article Carroll's [29] four-part definition is elaborated.

\section{Carroll's 1979 Conceptualization}

Carroll [29] explain that the four categories of responsibilities that an organisation has "are not mutually exclusive, nor are they intended to portray a continuum with economic concerns on one end and social concerns on the other" [29 p. 499] and also, the four kinds of responsibilities are neither cumulative nor additive but are arranged in a way to show the basic role that each plays in the developmental process of organisations in an order of importance. The author further explains that, though all the for kinds of responsibilities have always existed together in organisations, business history shows that in the early years of organisations the focus was on economic gain and then legal issues came up because of employees and working conditions and later, the issue of ethics and finally discretion or voluntarism. Additionally, any action or responsibility by an organisation may have economic, legal, ethical or discretionary reasons behind it.

\section{Economic Responsibility}

The first responsibility Carroll [29] talked about is economic responsibility. According to [29]) "the first and foremost social responsibility of business is economic in nature. Before anything else, the business institution is the basic economic unit in our society" [29 p. 500]. The author further explains that organisations have a responsibility to engage in productive activities either in the form of goods or services required by society and to be sold for profit. Adding that any other engagement of businesses is based on this basic assumption.

\section{Legal Responsibility}

The second responsibility Carroll [29] explains is legal. The assertion here is that, "just as society has sanctioned the economic system by permitting business to assume the productive role, as a partial fulfillment of the "social contract", it has also laid down the grounds rules, the laws and regulations under which business is expected to operate" [29 p.500]. The author explains that, society requires organisations to achieve its economic goals within a legal framework. Additionally, the dotted lines in figure 1 indicates that, although organisations have four different kinds of responsibilities, they must be met concurrently, so economic and legal responsibilities must go hand in hand, while the organisation is producing it must do it within stated laws.

\section{Ethical Responsibility}

By Carroll's [29] own assertion, despite both economic and legal responsibilities being embodiments of ethics, there are other behaviours and actions that are not written into law however society expects businesses to act in such ways. He further explains that ethical responsibilities are not properly defined and also hard for organisations to deal with. This is because issues concerning what is or isn't ethics is still on going. Carroll [29] ended by saying that society has expectations of organisations which go beyond legal requirements.

\section{Discretionary Responsibility}

The last responsibility that Carroll [29] explains is discretionary responsibility. He explains that these are responsibilities that are voluntary in nature and that they are left to individual judgement and choice. The author further explains that the decision to take up these roles are "guided only by a business's desire to engage in social roles not mandated, not required by law, and not generally expected of businesses in an ethical sense" [ 29 p.500].

\section{Overview of the Telecom Sector in Ghana}

The Total Cellular/Mobile Voice Subscriber Base in Ghana as at February, 2014 stood at 28,615,446. MTN had a marginal increase and maintained its position as the market leader with a subscriber base of 12,986,832 representing $45.38 \%$ of the total market share. Vodafone's subscriber base increased to $6,413,376$ which represent $22.41 \%$ of the total market share. Tigo had a marginal subscriber base increase, closing at 4,086,615 which 
represent $14.28 \%$ of the market share while Airtel increased its subscriber base to 3,537,316 representing $12.36 \%$ of the total market share. GLO decreased its subscriber base; its current subscriber base of $1,437,580$ represents $5.02 \%$ of the total market share. Expresso also, decreased its subscriber base to 153,727 representing $0.54 \%$ of the total market share. The information has been represented in a table and pie chart below [156].

\section{Methodology}

Questionnaires were distributed to students of the University of Ghana main campus. It was a non-probability purposive sampling. In all, a total of 500 questionnaires were distributed out of which 438 were found useful for the analysis, representing 87.6 per cent. The Statistical Package for Social Scientist (SPSS 18.0) software was used for this analysis. Data was then presented in tables, graphs and narratives. The questionnaire was divided into two sections; the first section was for demographic data. The second section was made up of close ended questions developed on a five point Likert scale ranging from 1strongly disagree, 2 - disagree, 3 - neutral, 4 - agree and 5 - strongly agree 5. Section B was subdivided into seven parts making up the six generic positioning strategies and the seventh is the extended positioning strategy proposed by Blankson [20]. These parts contain questions relating to the positioning strategies. The positioning strategies include price and quality (seven questions), image and ethos (eight questions), attributes (six questions), competition (six questions), user (five questions), application (four questions) and product class (four questions). A mean of above 3.5 was used as a benchmark.

\section{Results and Discussion}

Table 1. The demographic characteristics of the participants

\begin{tabular}{|c|c|c|c|}
\hline \multicolumn{2}{|c|}{ Variables } & \multirow{2}{*}{$\begin{array}{c}\text { Frequency } \\
155\end{array}$} & \multirow{2}{*}{$\begin{array}{c}\text { Percentage (\%) } \\
36\end{array}$} \\
\hline Age & Less than 20 & & \\
\hline & $21-30$ & 275 & 62.8 \\
\hline & $31-40$ & 1 & 0.2 \\
\hline \multirow[t]{2}{*}{ Gender } & Male & 229 & 52.5 \\
\hline & Female & 209 & 47.5 \\
\hline \multirow[t]{2}{*}{ Level of education } & Undergraduate & 425 & 97 \\
\hline & Postgraduate & 13 & 3 \\
\hline \multirow[t]{2}{*}{ Occupation } & Student & 429 & 97.9 \\
\hline & salaried worker & 9 & 2.1 \\
\hline \multirow[t]{5}{*}{ Mobile network operator } & MTN & 178 & 40.6 \\
\hline & Tigo & 86 & 19.6 \\
\hline & Vodafone & 105 & 24.0 \\
\hline & Airtel & 53 & 12.1 \\
\hline & Glo & 16 & 3.7 \\
\hline \multirow[t]{3}{*}{ Years of usage } & $0-5$ years & 282 & 64.4 \\
\hline & 6-10years & 137 & 31.3 \\
\hline & above 10 years & 19 & 4.3 \\
\hline
\end{tabular}

Table 2. Descriptive statistics and reliability of the variables

\begin{tabular}{|c|c|c|c|c|}
\hline Strategies & $\mathrm{N}$ & Means & Std. Deviation & Cronbach alpha $(\alpha)$ \\
\hline Price and quality & 438 & 3.0812 & 1.05369 & .750 \\
\hline Image and ethos & 438 & 3.5226 & .83195 & .737 \\
\hline Attributes & 438 & 3.0451 & .90613 & .770 \\
\hline Competition & 438 & 3.5683 & .80162 & .810 \\
\hline User & 438 & 2.4968 & .80011 & .736 \\
\hline Application & 438 & 3.3613 & 1.02152 & .768 \\
\hline Product class & 438 & 3.3409 & 1.12826 & \\
\hline
\end{tabular}


The table (2) above shows the reliability of the variables as well as the means and standard deviations of the variables. Per the Cronbach's alpha coefficient results, it is clear that the scale for the variables exceeded the minimum acceptable value of 0.5 for social science studies and thus proves to be adequate reliability $[57,109]$. The variables listed above represents the various positioning strategies that the customers perceive their network operators to be using. The mean results of the variables indicate how each of the variables performed from the 438 respondents' perspective. As a benchmark, a mean score above 3.5 [68] will mean customers agree that the network operators have adopted that particular strategy, below 2.5 suggest customers' disagree has adopted such a strategy, whereas figures between 2.5 and 3.5 means the customer is indifferent as to whether the service provider has adopted that strategy.

The means for the various variables ranges from a minimum of 2.4968 (User) to a maximum of 3.5683 (Competition). Thus, the least figure suggests that customers disagree that their network providers' adopt a user positioning strategy, whereas the highest mean also suggests the customers' perceive their network operators as pursuing the competition strategy. From the table above, the highest mean was scored by the competition strategy (3.5683), followed by "image and ethos" (3.5226). It can therefore be explained that these two are the most used strategies as perceived by the respondents. The next was Application (3.3613) and then to product class (3.3409). Price and quality and attribute scored 3.0812 and 3.0451 respectively, while the lowest was recorded by the "user" variable (2.496).

Table 3. The mean of the positioning strategies that telecom companies adopt

\begin{tabular}{|c|c|c|c|c|c|c|}
\hline Strategies & Service operator & $\mathbf{N}$ & Mean & Std deviation & $\mathbf{F}$ & $\mathbf{P}$ \\
\hline \multirow[t]{5}{*}{ Price and quality } & Mtn & 178 & 2.5616 & .83123 & 21.537 & .000 \\
\hline & Vodafone & 86 & 3.3355 & .95285 & & \\
\hline & Tigo & 105 & 3.4931 & 1.18522 & & \\
\hline & Airtel & 53 & 3.4016 & .89874 & & \\
\hline & Glo & 16 & 3.6250 & 1.02867 & & \\
\hline \multirow[t]{5}{*}{ Image and ethos } & Mtn & 178 & 3.0812 & 1.05369 & 2.366 & .052 \\
\hline & Vodafone & 86 & 3.4482 & .71465 & & \\
\hline & Tigo & 105 & 3.7451 & .96314 & & \\
\hline & Airtel & 53 & 3.5429 & .81257 & & \\
\hline & Glo & 16 & 3.4465 & .89022 & & \\
\hline \multirow[t]{5}{*}{ Attributes } & Mtn & 178 & 3.2813 & 1.06235 & 6.085 & .000 \\
\hline & Vodafone & 86 & 3.5226 & .83195 & & \\
\hline & Tigo & 105 & 2.7986 & .86859 & & \\
\hline & Airtel & 53 & 3.2735 & 1.03141 & & \\
\hline & Glo & 16 & 3.2243 & .76092 & & \\
\hline \multirow[t]{5}{*}{ Competition } & Mtn & 178 & 3.1604 & .83471 & 3.919 & .040 \\
\hline & Vodafone & 86 & 3.0000 & 1.12797 & & \\
\hline & Tigo & 105 & 3.0451 & .90613 & & \\
\hline & Airtel & 53 & 3.5486 & .72010 & & \\
\hline & Glo & 16 & 3.7275 & .74927 & & \\
\hline \multirow[t]{5}{*}{ User } & Mtn & 178 & 3.6359 & .97818 & 1.683 & .153 \\
\hline & Vodafone & 86 & 3.4340 & .63156 & & \\
\hline & Tigo & 105 & 2.9479 & .87288 & & \\
\hline & Airtel & 53 & 3.5683 & .80162 & & \\
\hline & Glo & 16 & 2.4648 & .76413 & & \\
\hline \multirow[t]{5}{*}{ Application } & Mtn & 178 & 2.6635 & .77103 & 5.273 & .000 \\
\hline & Vodafone & 86 & 2.3961 & .84805 & & \\
\hline & Tigo & 105 & 2.4679 & .82550 & & \\
\hline & Airtel & 53 & 2.7000 & .87331 & & \\
\hline & Glo & 16 & 2.4968 & .80011 & & \\
\hline \multirow[t]{5}{*}{ Product class } & Mtn & 178 & 3.1086 & .98534 & 2.510 & .041 \\
\hline & Vodafone & 86 & 3.6458 & 1.00316 & & \\
\hline & Tigo & 105 & 3.5149 & .98604 & & \\
\hline & Airtel & 53 & 3.4764 & .97599 & & \\
\hline & Glo & 16 & 3.2813 & 1.32248 & & \\
\hline
\end{tabular}


The table (3) above shows how the means of each variable as scored by the various network providers. This means were compared using an Analysis of Variance (ANOVA) to ascertain the F-ratio and the level of significance of that comparison. The results show that there was significant difference between the means of the various network providers for price and quality $(\mathrm{F}=21.537$; $p=.000)$, competition ( $\mathrm{F}=3.919 ; p=.040)$, Attributes ( $\mathrm{F}$ $=6.085 ; p=.000)$, application $(\mathrm{F}=5.273 ; p=.000)$ and product class $(\mathrm{F}=2.510 ; p=.041)$. This suggests that the means of these network providers with respect to the particular positioning strategies was significantly different from each other. This suggests to the researcher that the telecommunication networks either adopts or do not adopt these strategies differently, that is on different levels; some with a greater degree and others with a lesser degree. Only two of the variables were found not to be significant; these include image and ethos $(\mathrm{F}=2.366 ; p=.052)$ and user $(\mathrm{F}=$ $1.683 ; p=.153$ ). This means that for these two variables the respondents view the strategies of these network providers as not being significantly different from each other. In this view, the degrees to which telecommunication network providers adopt or do not adopt these strategies are the same. The table below shows the mean difference of the various comparisons, to ascertain which network providers' mean was larger or smaller.

Table 4. The mean difference of the positioning strategies that telecom companies adopt

\begin{tabular}{|c|c|c|c|c|c|c|}
\hline Strategies & Service operator & MTN & Vodafone & Tigo & Airtel & Glo \\
\hline \multirow[t]{5}{*}{ Price and quality } & Mtn & 1 & $-0.77397^{*}$ & $-0.93156^{*}$ & $-0.84004 *$ & $-1.06342 *$ \\
\hline & Vodafone & & 1 & -0.15758 & 0.06607 & 0.28945 \\
\hline & Tigo & & & 1 & -0.0361 & 0.13187 \\
\hline & Airtel & & & & 1 & 0.22338 \\
\hline & Glo & & & & & 1 \\
\hline \multirow[t]{5}{*}{ Image and ethos } & Mtn & 1 & $0.47496^{*}$ & $0.42569^{*}$ & 0.36181 & 0.20143 \\
\hline & Vodafone & & 1 & 0.04926 & 0.11315 & 0.21353 \\
\hline & Tigo & & & 1 & 0.06389 & 0.22426 \\
\hline & Airtel & & & & 1 & 0.16038 \\
\hline & Glo & & & & & 1 \\
\hline \multirow[t]{5}{*}{ Attributes } & Mtn & 1 & 0.29689 & 0.09465 & 0.00167 & 0.16696 \\
\hline & Vodafone & & 1 & 0.20224 & 0.29856 & 0.46385 \\
\hline & Tigo & & & 1 & 0.09632 & 0.26161 \\
\hline & Airtel & & & & 1 & 0.16529 \\
\hline & Glo & & & & & 1 \\
\hline \multirow[t]{5}{*}{ Competition } & Mtn & 1 & -0.17888 & -0.08735 & 0.11461 & $0.60065^{*}$ \\
\hline & Vodafone & & 1 & 0.09153 & 0.29349 & 0.77953* \\
\hline & Tigo & & & 1 & 0.20196 & $0.68801 *$ \\
\hline & Airtel & & & & 1 & 0.48605 \\
\hline & Glo & & & & & 1 \\
\hline \multirow[t]{5}{*}{ User } & Mtn & 1 & -0.19876 & 0.06869 & 0.00315 & 0.23523 \\
\hline & Vodafone & & 1 & 0.26745 & 0.19560 & 0.03647 \\
\hline & Tigo & & & 1 & 0.07185 & -0.30392 \\
\hline & Airtel & & & & 1 & 0.23208 \\
\hline & Glo & & & & & 1 \\
\hline \multirow[t]{5}{*}{ Application } & Mtn & 1 & $-0.53726^{*}$ & $-0.40628^{*}$ & -0.36784 & -0.17268 \\
\hline & Vodafone & & 1 & 0.13098 & 0.16942 & 0.36458 \\
\hline & Tigo & & & 1 & 0.38440 & 0.23360 \\
\hline & Airtel & & & & 1 & 0.19517 \\
\hline & Glo & & & & & 1 \\
\hline \multirow[t]{5}{*}{ Product class } & Mtn & 1 & -0.07245 & 0.33638 & 0.30018 & 0.29777 \\
\hline & Vodafone & & 1 & 0.40882 & 0.37262 & 0.37022 \\
\hline & Tigo & & & 1 & 0.03620 & 0.03860 \\
\hline & Airtel & & & & 1 & -0.00240 \\
\hline & Glo & & & & & 1 \\
\hline
\end{tabular}




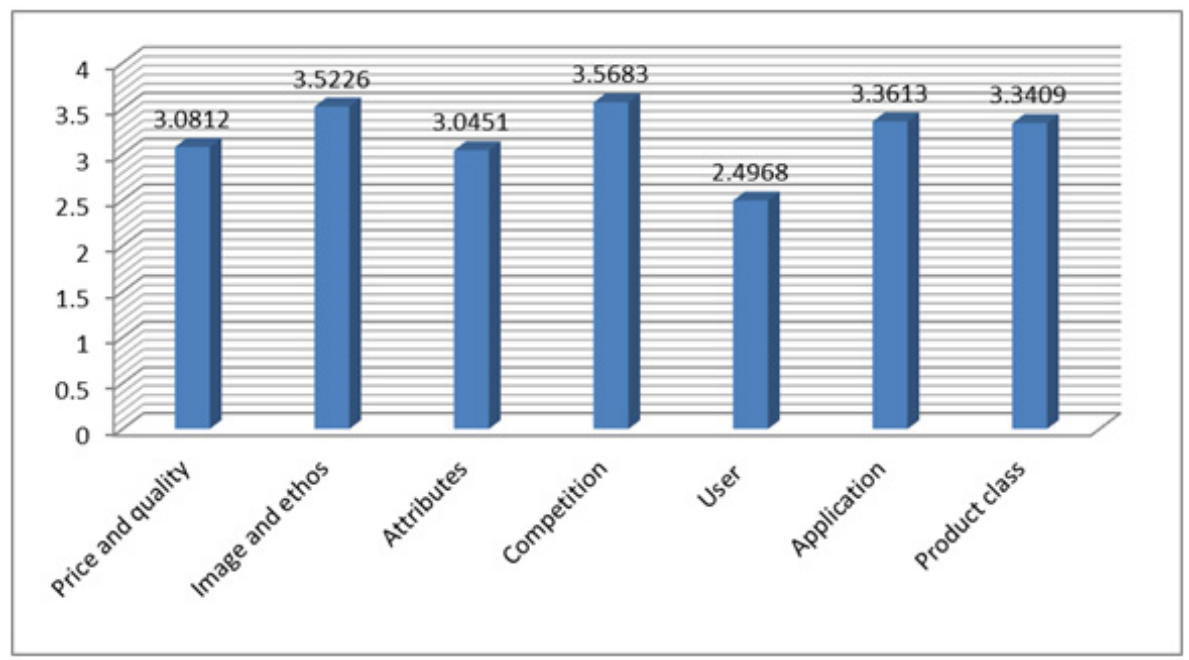

Figure 1. The dominant positioning strategy adopted by the telecom company

The table (4) above shows the mean difference of the positioning strategies that telecom companies adopt, which is a comparison of the means scored by the various network providers in connection with the positioning strategies. Particularly, the mean differences were extracted from a Hochberg Post Hoc analysis; this tool was used because the sample sizes of the units of analysis were very different from each other [47]. With respect to price and quality, MTN was found to have a greater mean than Tigo $(-0.93156, p \leq 0.05)$ and Vodafone $(-0.77397, p \leq 0.05)$, Airtel $(-0.84004, p \leq 0.05)$ and Glo $(-1.06342, p \leq 0.05)$; this difference was found to be significant.

Under this same variable, Vodafone also had a higher mean than Airtel. These results suggest that MTN adopts a price and quality positioning strategy more than its counterparts. With respect to competition, Glo was found to have a greater mean than MTN $(0.60065, \mathrm{p} \leq 0.05)$, Vodafone $(0.77953, \mathrm{p} \leq 0.05)$ and Tigo $(0.68801, \mathrm{p} \leq 0.05)$. This also suggests plainly that Glo is considered by its customers as adopting a competitive strategy more than its counterparts. With respect to image and ethos, the result shows that MTN has a greater mean than Vodafone $(0.47496, \mathrm{p} \leq 0.05)$ and Tigo $(0.42569, \mathrm{p} \leq 0.05)$.

Lastly, with regards to application, MTN again has a greater mean than Vodafone $(0.53726, \mathrm{p} \leq 0.05)$ and Tigo $(0.40628, \mathrm{p} \leq 0.05)$. Majority of the mean differences between the service providers were not statistically significant; which can mean that the means of these service operators with regards to those strategies are not different from each other.

The figure above displays the customers' view of which positioning strategy is highly used by the network providers. The results show that the "competition" strategy had the highest mean (3.5683) to show that it was the most dominant strategy used by telecommunication networks in Ghana. Followed by "image and ethos" (3.5226) and then to "application" (3.3613). On the other hand, "user" strategy had the lowest mean (2.4968), suggesting it was the lowest positioning strategy adopted by the network service providers.

\section{Discussion of Results}

The mobile telephony market is one of the fastest-growing service segments in telecommunications. Mahmoud and Hinson [87] suggest that, Ghana's telecommunication sector has gone through several stages after independence. These stages have finally evolved the telecommunication industry as one of the leading innovative industries in Ghana. This great increase in teledensity is attributed to the establishment and the effectiveness of the NCA [157], who is regulator of the industry. This has also led to increased competition as asserted by Osiakwan [108] and Goni [55].

As a result of the growth in the industry, the telecommunication networks providers have adopted several strategies in their bid to win over the mobile market; these include competition, user, price and quality, attributes and product class strategies [67]. A recently emerging strategy as a result of concerns for the social environment ([146]) is the image and ethos strategy. Blankson [20] described this as the seventh strategy and explains it is basically an attempt by firms to differentiate themselves along the lines of good external image, ethos and good citizenry [33, 56, 92, 133].

The current study seeks to assess the various positioning strategies being used by the network providers. In connection to this, the results from the descriptive statistic of the positioning strategies showed that from the customers' point of view, the telecommunication companies in Ghana only adopt two strategies (competition and image and ethos) using the 3.5 mean score as benchmark [68]. This answered objective two which was to examine the different positioning strategies employed by the telecom companies in Ghana. The customers are indifferent about four of the strategies (product class, 
attributes, price and quality and application) and disagree that their service providers adopt the "user" strategy. The implication to this could be that, customers are not in tune with the telecom operators on the use of brand ambassadors for promotional activities. The discussion would be focused on these two (competition and image and ethos) as well as on the variables that showed a significant difference between the various network providers (competition, product class, attributes, price and quality and application).

From the results, the study identified that competition (3.5683) was the most dominantly used positioning strategy in the telecommunication industry; this is in answer to objective three which was to examine the dominant positioning strategy employed by the telecom firms. This finding supports the results of several scholars $[55,108]$, who postulated that the industry was a very competitive one, and also suggested that the motive for most of the promotional activities in the sector is to fight off competition. With regard to the individual network providers, the result also revealed that Glo had a greater mean than MTN $(0.60065, \mathrm{p} \leq 0.05)$, Vodafone $(0.77953$, $\mathrm{p} \leq 0.05)$ and Tigo $(0.68801, \mathrm{p} \leq 0.05)$ with regard to competition; this indicates that Glo adopts the competitive strategy more than any other network provider. This also suggests plainly that Glo is considered by customers as the most competitive network provider. This could well be as a result of Glo's penetrative strategy in attempts to break into the telecommunication market in Ghana being the last of the network providers to start operations in Ghana.

The current study revealed that the companies in the mobile telecommunication industry use the image and ethos as a positioning strategy (image and ethos $=3.5226$ ). This result also answers objective one, which sought to assess whether the firms were adopting CSR (image and ethos) as a positioning strategy. This is supportive of previous literature describing some of the companies in the telecommunication industry as being CSR brands $[63,152]$. Guerrera et al. [56] also explain the strategy is adopted by several firms; with the aim of differentiating themselves as good citizens and as socially responsible firms. This may well be the situation in reality as most of the telecommunication companies' undertake television programs that show to the public the kind of CSR activities the firm is and has been engaging in. For example, MTN announced its commitment to pump over GH $\phi 4$ million into various community projects to enhance many more lives in the various communities [155]; Vodafone also recently introduced the "Vodafone Health Line" [154], whereas Airtel also has the "Airtel touching lives program" [153].

The ANOVA result did not show a significant difference between the firms' adoption of this strategy (image and ethos); in other words, the magnitude of the usage of this strategy was not very different from each of the network providers. However, further statistical probing with the Hochberg Post Hoc analysis revealed a significant difference existed only between the CSR strategy of MTN, Vodafone and Tigo, but the rest were the same. The Hochberg Post Hoc analysis results claimed that MTN from the perspective of customers, adopts the CSR positioning strategy more than Vodafone and Tigo. For instance, MTN was found to have a greater mean than Tigo $(0.42569, p \leq 0.05)$ and Vodafone $(0.47496, p \leq 0.05)$ with respect to image and ethos. This difference was found to be significant. This finding was supported in the literature, in that MTN was awarded the "Ghana Club 100 Best Company in CSR" by Ghana Investment Promotion Centre (GIPC) during their 2009 edition of annual awards scheme for corporate organisations dubbed "Ghana Club 100" GIPC Report [152].

Even though the means of such positioning strategies as user; attributes; price and quality; application and product class indicate that customers did not agree or were indifferent that network providers were adopting such strategies, the results from the ANOVA test reveal that there were still some significant differences between the levels of adoption for each service provider. For example, the current study revealed that customers are indifferent as to whether telecommunication companies in Ghana adopt a "price and quality" strategy (3.0812). This was not in line with earlier literature. Goni [55] for example suggests that, the competition in the telecommunication industry is not only in terms of market share but also in term of affordable prices and the quality of service.

On the individual level, respondents indicated that MTN uses the "price and quality" strategy more than any other network providers. This could well be because, within the time of the data collection, MTN had just introduced some new promotional packages (MTN Aben woha promo).

\section{Major Finding}

Findings from the analysis performed from the study have been discussed in relation to the objectives of the study.

\section{To examine if the telecom companies in Ghana have employed CSR (image and ethos) as a positioning strategy.}

The study adopted a likert scale and stipulated that figures above the 3.5 threshold were to be considered as indicating "agree". In view of this, the result from the studies indicated that respondent or customers of the various networks agree that their network providers were adopting image and ethos as a positioning strategy (image and ethos $=3.5226$ ). This was also somewhat supported in previous studies [63, 152] for example; Hinson and Kodua [63] noted that there has been a lot of concentration on CSR activities among the telecommunication firms. In this respect, Guerrera et al. [56] explain the strategy is adopted by these firms with the aim of differentiating themselves as good citizens and socially responsible firms. 
To examine the different positioning strategies employed by the telecom companies in Ghana.

The results from the descriptive statistic of the positioning strategies showed that from the customers' point of view, the telecommunication companies in Ghana only adopt two strategies using the 3.5 benchmark indicated above. These strategies include the competition $[46,106]$ and image and ethos strategy $[63,152,153,154]$.

\section{To examine the dominant positioning strategies employed by the telecom companies in Ghana.}

The study identified that competitive strategy was the most dominantly used positioning strategy in the telecommunication industry. This finding supports the results of several scholars Osiakwan [108] and Goni [55], who postulated that the industry was a very competitive one, and also suggested that the motive for most of the promotional activities in the sector is to fight off competition. Glo, from the perspective of the customers adopts the competitive strategy more than any of the other network providers. Glo can therefore be said to be considered by customers as the most competitive network provider.

\section{Conclusions}

The thought of an organisation pinning its brand on corporate social responsibility would have been unthinkable in times past but in the $21^{\text {st }}$ century, organisations have realised the power of consumers and their concern for their environment and it will be foolhardy on the part of organisational leaders to brush this aside. To ignore the relevance of corporate social responsibility or to treat it as a token rather than an integral part of the corporate strategy could have dire financial, legal and reputational consequences for the organisation.

Whichever concept or conceptualisation that an organisation decides to view corporate social responsibility is neither here nor there. The most important issues are that, the organisation and its actors are seen to show a keen interest in the welfare of the communities in which they operate. Thereby setting themselves apart from competitors and drawing a sense of affinity towards the organisation and its brand. To put it succinctly, organisations should be seen as thriving on the wings of its image and ethos or better still as a brand that is seen as positioning itself as a socially responsible organisation and this has far more reaching benefits that the cost incurred in practicing it.

\section{Recommendation}

Future studies should be carried out in other jurisdictions to affirm the validity of the results. Also a longitudinal study with respect to the positioning strategies of firms should be carried out to ascertain the changing trends that can impact and affect the positioning strategy of the firm. Further studies should also be conducted into the positioning dimensions that firms use to position their offerings and especially within the service sector.

\section{REFERENCES}

[1] Aaker, D. A., \& Shansby, J. (1982). Positioning your product. Business Horizons 25(3), 56-62.

[2] Ackerman, R. W., \& Bauer, R. A. (1976). Corporate social responsiveness. Reston, VA: Reston Publishing.

[3] Alden, D. L., Steenkamp, J. \& Batra, R. (1999). Brand positioning through advertising in Asia, North America, and Europe; The Role of Global Consumer Culture. Journal of Marketing, 63 (1), 75-87.

[4] Alpert, L. \& Gatty, R. (1969). Product positioning by behavioural life-styles, Journal of Marketing, 33, 65-69.

[5] Altman, B. W. (1998), Corporate Community Relations in the 1990s: A Study in Transformation, Business and Society 37 (2), 221-228.

[6] Amaeshi, K. M., Adi, B. C., Ogbechie, C., \& Olufemi, O. A. (2006). Corporate Social Responsibility in Nigeria: Western Mimicry or Indigenous Influences? Journal of Corporate Citizenship, 24, 83-99.

[7] Anselmsson, J. \& Johansson, U. (2007). Corporate social responsibility and the positioning of grocery brands: An exploratory study of retailer and manufacturer brands at point of purchase. International Journal of Retail \& Distribution Management, 35(10), 835 - 856.

[8] Arnott, D.C. (1992). Bases of financial services positioning in the personal pension, life assurance and personal equity plan sectors. PhD thesis, Manchester Business School, University of Manchester, UK.

[9] Arnott, D.C. (1993). Positioning: redefining the concept. Research Papers 81, Warwick Business School, Coventry.

[10] Arnott, D.C. (1994). Positioning: on defining the concept, Marketing Educator' Group (MEG). Conference Proceedings, University of Ulster, Coleraine, NI, 4-6 July.

[11] Arnott, D.C., \& Easingwood, C.J. (1994). Positioning in services: an hypothetical typology of competitive bases. 23rd EMAC Conference Proceedings, 1, University of Limburg, Maastricht, 17-20.

[12] Asongu, J. J. (2007b). Innovation as an argument for corporate social responsibility. Journal of Business and Public Policy, 1(3), 1-21.

[13] Asongu, J.J. (2007a). Strategic Corporate Social Responsibility in Practice. Greenview Publishing Company.

[14] Baker, M. J. (1981). Services - salvation or servitude? The Quarterly Review of Marketing, 7 -18.

[15] Balasubramanian, N. K., Kimber, D., Pussayapibul, N., \& Davids, P. (2005). Emerging Opportunities or Traditions 
Reinforced? An Analysis of the Attitudes Towards CSR, and Trends of Thinking about CSR, in India. Journal of Corporate Citizenship, 17, 79-92.

[16] Bernstein, D. (1992). Company image \& reality: A critique of corporate communications. Cassell Educational Ltd., London.

[17] Bhattacharya, C. B., \& Sen, S. (2003). Consumer-company identification: A framework for understanding consumers' relationship with companies. Journal of Marketing, 67(2), $76-88$.

[18] Bitner, M.J. (1997). Services marketing: perspectives on service excellence. Journal of Retailing, 73 (1), 3-6.

[19] Blankson, C. (2001). Some issues about the concept of positioning: an overview. In Atlantic Marketing Association Conference.

[20] Blankson, C. (2008). Consumer perceptions of UK plastic card brands' marke positions and positioning strategies. Journal of Retail Marketing Management Research, 1(2), $1-16$.

[21] Blankson, C., Kalafatis, S. P., Cheng, J. M. S., \& Hadjicharalambous, C. (2008). Impact of positioning strategies on corporate performance. Journal of Advertising Research, 48(1), 106-22.

[22] Blankson, C., \& Kalafatis, S. P. (1999). Issues and challenges in the positioning of service brands: a review. Journal of Product \& Brand Management, 8(2), 106-118.

[23] Blankson, C., \& Kalafatis, S. P. (2007). Congruence between positioning and brand advertising. Journal of Advertising Research, 47(1), 79.

[24] Blowfield, M. (2004). Implementation Deficits of Ethical Trade Systems: Lessons from the Indonesian Cocoa and Timber Industries. Journal of Corporate Citizenship, 13, 77-90.

[25] Bowen, H.R. (1953). Social Responsibilities of the Businessman. Harper \& Row, New York, NY, 6.

[26] Brown, T. J., \& Dacin, P. (1997). The company and the product: Corporate beliefs and consumer product responses. Journal of Marketing, 61(1), 68-84.

[27] Brummer, J. (1991), Corporate Responsibility and Legitimacy (Greenwood Press, New York).

[28] Buttle, F. (1986). Unserviceable concepts in service marketing. The Quarterly Review of Marketing, 8-14.

[29] Carroll, A. B. (1979). A Three-Dimensional Conceptual Model of Corporate Performance. The Academy of Management Review 4(4), 497-505.

[30] Carroll, A. B. (1999). Corporate social responsibility. Business and Society, 38 (3), 268-96.

[31] Chahal, H., \& Sharma, R. D. (2006). Implications of corporate social responsibility on marketing performance: a conceptual framework. Journal of Services Research, 6(1), 205-216.

[32] Chappell, T. (1993). The soul of a business: Managing for profit and the common good. Des Plaines, IL: Bantam.

[33] Cobb, R. (2002). Selling Responsibility. Marketing Business
Magazine, 110, 25-27.

[34] Crawford, C. M. (1985). A New Positioning Typology. Journal of Product Innovation Management, 1(4), 243-53.

[35] Davis, K. (1973). The Case For and Against Business Assumption of Social Responsibility. Academy of Management Journal, 3,12-322.

[36] Dawkins, D., \& Lewis, S. (2003). CSR in stakeholder expectations: and their implication for company strategy. Journal of Business Ethics, 44 (2/3), 185-93.

[37] Dibb, S., \& Simkin, L. (1991). Targeting, segments and positioning. International Journal of Retail \& Distribution Management, 19 (3), 4-10.

[38] Dillon, W. R., Domzal, T. \& Madden, T.J.(1986). Evaluating Alternative Product Positioning Strategies. Journal of Advertising Research, 26(4), 29-35.

[39] Dolan, C. S., \& Opondo, M. (2005). Seeking Common Ground: Multi-stakeholder Processes in Kenya's Cut Flower Industry. Journal of Corporate Citizenship, 18, 87-98.

[40] Donnelly, J.H., Brown, L.L., \& Thompson, T.W. (1985). Marketing Financial Services, Irwin Professional Publishing, Burr Bridge, IL.

[41] Drumwright, M. E. (1996). Company advertising with a social dimension: The role of noneconomic criteria. The Journal of Marketing, 71-87.

[42] Du, S., Bhattacharya, C. B., \& Sen, S. (2007). Reaping relational rewards from corporate social responsibility: The role of competitive positioning. International Journal of Research in Marketing, 24(3), 224-241.

[43] Easingwood, C.J., \& Mahajan, V. (1989). Positioning of financial services for competitive strategy. Journal of Product Innovation Management, 6, 207-19.

[44] Eells, R. S. F., \& Walton, C. C. (1961). Conceptual foundations of business: an outline of major ideas sustaining business enterprise in the Western World. RD Irwin.

[45] Egels, N. (2005). CSR in Electrification of Rural Africa: The Case of ABB in Tanzania. Journal of Corporate Citizenship, $18,75-85$.

[46] Eshghi, A., Haughton, D., \& Topi, H. (2007). Determinants of customer loyalty in the wireless telecommunications industry. Telecommunications policy, 31(2), 93-106.

[47] Field, H. (2005) The ecology of Hendra virus and Australian bat lyssavirus. PhD thesis, The University of Queensland, Brisbane.

[48] Fill, C. (1999). Marketing Communications: Contexts, Contents and Strategies. 2nd ed. Hemel Hempstead, U.K.; Prentice-Hall Europe.

[49] Fisher, R.J. (1991). Durable differentiation strategies for services. Journal of Services Marketing, 5 (1), 19-28.

[50] Freeman, R.E. \& Liedtka, J. (1991, July-August). Corporate social responsibility: A critical approach. Business Horizons, 34(4): 92-98.

[51] Freeman, R.E. (1984). Strategic management: A stakeholder perspective. Englewood Cliffs, NJ: Prentice Hall. 
[52] Friedman, M. (1962). Capitalism and freedom. Chicago: University of Chicago Press.

[53] Garriga E. \& Mele D. (2004), Corporate Social Responsibility Theories: Mapping the Territory, Journal of Business Ethics 53, 51-71.

[54] Glynn, W. J., \& Barnes, J. G. (1995). Understanding services management. John Willey and Sons Ltd.

[55] Goni, A. A. (2011). Assessing the operational performance of Vodafone Ghana Company Limited in the Ghanaian Telecommunication Industry (Doctoral dissertation, Kwame Nkrumah University of Science and Technology). Retrieved from

http://dspace.knust.edu.gh:8080/jspui/bitstream/123456789/ 4475/1/Adams\%20Abu \%20thesis.pdf

[56] Guerrera, F. \& Firn, D. (2001). Charity group drops bank in fight back on animal rights. Financial Times Newspaper, Monday, April 23, 6

[57] Hair, J.F., Black, W.C., Babin, B.J., \& Anderson, R.E. (2010). Multivariate data analysis. Pearson Prentice-Hall, Upper Saddle River.

[58] Hamann, R., Kapelns, P., Sonnenberg, D., Mackenzie, A., \& Hollesen, P. (2005). Local Governance as a Complex System: Lessons from Mining in South Africa, Mali and Zambia. Journal of Corporate Citizenship, 18, 61-73.

[59] Hassan, S. \& Craft, S. (2012). Examining world market segmentation and brand positioning strategies. Journal of Consumer Marketing, 29(5), 344 - 356.

[60] Hinson R. (2011). Online CSR reportage of Award-winning versus non award-winning banks in Ghana. Journal of Information Communication \& Ethics in Society, 9(2), 102-115

[61] Hinson, R. \& Ndhlovu T. P. (2011). Conceptualizing Corporate Social Responsibility (CSR) and Corporate Social Investment (CSI): The South African Context. Social Responsibility Journal, 7(3), 332 - 346.

[62] Hinson, R. (2011). Corporate Social Responsibility (CSR) reportage on websites and in annual reports: The Case of CAL Bank in Ghana. Corporate Ownership and Control, 8(2), 190-202.

[63] Hinson, R. E. \& Kodua P. (2012). Examining the marketing-corporate social responsibility nexus. International Journal of Law and Management, 54(5), 332-344.

[64] Hinson, R., Boateng, R. \& Madichie N. (2010). Corporate Social Responsibility activity reportage on bank websites in Ghana. International Journal of Bank Marketing, 28 (7), 498-518.

[65] Hooley, G., \& Greenley, G. (2005). The resource underpinnings of competitive positions. Journal of Strategic Marketing, 13(2), 93-116.

[66] Hooley, G., \& Saunders, J. (1993). Competitive Positioning: The Key to Market Success, Prentice Hall, Hemel Hempstead.

[67] Hooley, J. A., Saunders \& Piercy, N.F. (1998). Marketing Strategy \& Competitive Positioning. 2nd ed. London; Prentice Hall Europe.
[68] Ibidunni, O. S., Iyiola, O., \& Ibidunni, A. S. (2014). Product innovation, a survival strategy for small and medium enterprises in Nigeria. European Scientific Journal, 10(1).

[69] Jamali, D. \& Mirshak, R. (2007). Corporate social responsibility (CSR): Theory and practice in a developing country context. Journal of Business Ethics, 72, 243-262.

[70] Javalgi, R.G., Joseph, W.B., \& Gombeski, W.R. (1995). Positioning your service to target key buying influences: the case of referring physicians and hospitals. Journal of Services Marketing, 9(5), 42-52.

[71] Jones, T. M. (1983), An Integrating Framework for Research in Business and Society: A Step Toward the Elusive Paradigm? , Academy of Management Review 8 (4), 559565.

[72] Kara, A., Kaynak, E., \& Kucukemiroglu, O. (1996). Positioning of fast-food outlets in two regions of North America: a comparative study using correspondence analysis. Journal of Professional Services Marketing, 14(2), 99-119.

[73] Kaufman, A., Tiantubtim, E., Pussayapibul, N., \& Davids, P. (2004). Implementing Voluntary Labour Standards and Codes of Conduct in the Thai Garment Industry. Journal of Corporate Citizenship, 13, 91-9.

[74] Klein, J., \& Dawar, N. (2004). Corporate social responsibility and consumers' attributions and brand evaluations in product-harm crisis. International Journal of Research in Marketing, 23, 203-17.

[75] Kotler, P. (1997). Marketing Management Analysis, Planning, Implementation, and Control. 9th ed., Prentice-Hall, Englewood Cliffs, NJ.

[76] Kotler, P. (2000). Marketing Management (The Millenium Edition). Upper Saddle River, NJ: Prentice-Hall.

[77] Kuada, J., \& Hinson, R. E. (2012). Corporate social responsibility (CSR) practices of foreign and local companies in Ghana. Thunderbird International Business Review, 54(4), 521536.

[78] Kuada, J., \& Hinson, R. E. (2012). Corporate social responsibility (CSR) practices of foreign and local companies in Ghana. Thunderbird International Business Review, 54(4), 521536.

[79] Lantos, G.P. (2001). The boundaries of strategic corporate social responsibility. Journal of Consumer Marketing, 18(7), 595-630.

[80] Levitt, T. (1981). Marketing intangible products and product intangibles. Harvard Business Review, May-June.

[81] López, N. V., \& Boluda, I. K. (2006). International positioning of leading brands through internet: globalize or do not globalize? Innovative marketing, 2(4), 62-74.

[82] Lovelock, C. H. (1983). Classifying services to gain strategic marketing insights. Journal of Marketing, 9-20.

[83] Luken, R., \& Stares, R. (2005). Small Business Responsibility in Developing Countries: A Threat or an Opportunity? Business Strategy and the Environment, 14 $38-53$.

[84] Lund-Thomsen, P. (2004). Towards a Critical Framework on 
Corporate Social and Environmental Responsibility in the South: The Case of Pakistan'. Development, 47(3), 106-113.

[85] Maggard, J. P. (1976). Positioning revisited. Journal of Marketing, 40(1), 63-66.

[86] Mahmoud M. \& Hinson, R. (2012a). Market orientation in a developing economy public institution: revisiting the Kohli and Jaworski framework. International Journal of Public Sector Management 25(2), 88-102.

[87] Mahmoud, M. A., \& Hinson, R. E. (2012b). Market orientation, innovation and corporate social responsibility practices in Ghana's telecommunication sector. Social Responsibility Journal, 8(3), 327-346.

[88] Maignan, I. \& Ferrell, O. C. (2001). Corporate citizenship as a marketing instrument: concepts, evidence and research directions. European Journal of Marketing, 35(3/4) 457-484.

[89] Maignan, I. (2001). Consumers' perceptions of corporate social responsibilities: a cross cultural comparison. Journal of Business Ethics, 30(1), 57-72.

[90] Maon, F., Lindgreen, A. \& Swaen, V. (2009). Designing and implementing corporate social responsibility: an integrative framework grounded in theory and practice, Journal of Business Ethics, 87:71-89

[91] Marin, L., \& Ruiz, S. (2007). "I need you too!" corporate identity attractiveness for consumers and the role of social responsibility. Journal of Business Ethics, 71(3), 245260.

[92] Marketing (1996). Midland Ties in with Charity Trio, January 11,8 and 25-27.

[93] Mason, E. S. (1960). The Corporation in Modern Society. Harvard University Press, Cambridge, MA.

[94] McDonald, L. M., \& Rundle-Thiele, S. (2008). Corporate social responsibility and bank customer satisfaction: A research agenda. International Journal of Bank Marketing, 26(3), 170-182.

[95] McGuire, J. (1963). Business and society. New York: McGraw-Hill.

[96] McMahon, T. F. (1986), Models of the Relationship of the Firm to Society, Journal of Business Ethics 5, 181-191.

[97] McWilliams, A., \& Siegel, D. (2001). Corporate social responsibility: A theory of the firm perspective. Academy of management review, 26(1), 117-127.

[98] Melé, P. (2006). La producción del patrimonio urbano. Ciesas.

[99] Middleton, V.T.C. (1983). Product marketing - goods and services compared. The Quarterly Review of Marketing, Summer, 1-10

[100] Moskowitz, M. (1972). Choosing socially responsible stocks. Business and Society. 1, 71-75.

[101] Mühlbacher, H., Dreher, A., \& Gabriel-Ritter, A. (1994). MIPS-Managing industrial positioning strategies. Industrial Marketing Management, 23(4), 287-297.

[102] Murray, K.B., \& Vogel, C.M. (1997). Using a hierarchy-of-effects approach to gauge the effectiveness of corporate social responsibility to generate goodwill toward the firm: financial versus non-financial impacts. Journal of Business Research, 38, 141-59.

[103] Myers, J. H. \& Tauber, E. (1977). Market structure analysis, American Marketing Association, Chicago, IL.

[104] Nielsen, M. E. (2005). The Politics of Corporate Responsibility and Child Labour in the Bangladeshi Garment Industry. International Affairs, 81(3), 559-80.

[105] Nylen, D. W. (1990). Marketing decision-making handbook. Prentice Hall, Englewood Cliffs, NJ., G113 - G 116.

[106] Nysveen, H., Pedersen, P. E., \& Thorbjørnsen, H. (2005). Explaining intention to use mobile chat services: moderating effects of gender. Journal of Consumer Marketing, 22(5), 247-256.

[107] Ofori, D. \& Hinson, R. (2007). Corporate Social Responsibility (CSR) Perspectives Of Leading Firms In Ghana. Corporate Governance, 7(2), 178 - 193.

[108] Osiakwan, E. M.K (2003). Ghana's Internet Industry for West Africa Magazine Report; Monitoring the WSIS Targets A Mid-Term Review. ITU, Geneva

[109] Parasuraman, A., Zeithaml, V. A., \& Berry, L. L. (1988). Servqual. Journal of retailing, 64(1), 12-40.

[110] Park, C. W., Jaworski, B. J \& Maclnnis, D. (1986). Strategic Brand Concept-Image Management. Journal of Marketing, 50 (Oct), 135-145.

[111] Parket. R., \& Eibert, H. (1975). Social responsibility: The underlying factors. Business Horizons. 18: 5-10.

[112] Payne, A. \& Clark, M. (1995). Marketing services to external markets. In Glynn, W. J., \& Barnes, J. G. (Eds.). (1995). Understanding services management. John Wiley \& Sons, Chichester, 322-369.

[113] Pechmann, C. \& Ratneshwar, S. (1991). The Use of Comparative Advertising for Brand Positioning; Association versus Differentiation. Journal of Consumer Research, $18(2), 145-60$

[114] Porter, M. E. (1996). What is strategy? Harvard Business Review, 74(6), 61-78.

[115] Porter M. E. \& Kramer M.R. (2011), The Big Idea: Creating Shared Value, Harvard Business Review, 89 (1/2)

[116] Porter, M. E., \& Kramer, M. R. (2006). The link between competitive advantage and corporate social responsibility. Harvard business review, 84(12), 78-92.

[117] Prasad, B. C. (2004). Globalisation, Free Trade and Corporate Citizenship in Pacific Forum Island Countries. Journal of Corporate Citizenship, 13, 65-76.

[118] Preston, L. E. (1975), Corporation and Society: The Search for a Paradigm, Journal of Economic Literature 13 (2), 434 454.

[119] Prieto - Carrón, M., Lund - Thomsen, P. E. T. E. R., Chan, A., Muro, A. N. A., \& Bhushan, C. (2006). Critical perspectives on CSR and development: what we know, what we don't know, and what we need to know. International Affairs, 82(5), 977-987.

[120] Prince, M. (1990). How consistent is the information in positioning studies? Journal of Advertising Research, 30 
$(3 / 4), 25-30$.

[121] Ries, A. \& Trout J. (1972). The positioning era commeth. Advertising age, 24, 35-38.

[122] Ries, A., \& Trout, J. (1986). Positioning: The battle for your mind (pp. 34-71). W. Sabin, \& M. Hamerling (Eds.). New York: McGraw-Hill.

[123] Rigger, W. (1995). Positioning in theory and practice: towards a research agenda. $24^{\text {th }}$ EMAC Conference Proceedings, Vol. 1, 16-19 May, ESSEC, France, 991-1009

[124] Rossiter, J. R. \& Percy, L. (1997). Advertising Communications \& Promotion Management. New York; The McGraw-Hill Companies, Inc.

[125] Schmidt, S. J., \& Tropp, J. (2009). Die Moral der Unternehmenskommunikation. Lohnt es sich, gut zu sein.

[126] Schrage, E. J., \& Ewing, A. P. (2005). The Cocoa Industry and Child Labour. Journal of Corporate Citizenship, 18, 99112.

[127] Sekhar, K. M. (1989). Positioning strategies for the British commercial vehicles, M.Phil. Thesis, University of Strathclyde, Glasgow, UK.

[128] Sen, S., \& Bhattacharya, C. B. (2001). Does doing good always lead to doing better? Consumer reactions to corporate social responsibility. Journal of Marketing Research, 38(2), 225-243.

[129] Sen, S., Bhattacharya, C. B., \& Korschun, D. (2006). The role of corporate social responsibility in strengthening multiple stakeholder relationships. Journal of the Academy of Marketing Science, 34(2), 158-166.

[130] Smith, R.E. \& Lusch, R.F. (1976). How advertising can position a brand. Journal of Advertising Research, 16(1), $37-43$.

[131] Snider, J., Hill, R. P., \& Martin, D. (2003). Corporate social responsibility in the $21^{\text {st }}$ century: a view from the world's most successful firms. Journal of Business Ethics, 48(2), $175-187$.

[132] Soloman, R., \& Hansen. K. (1985). It's good business. New York: Atheneum

[133] The Economist (2008). Just good business. The Economist, 17 January.

[134] Trout, J. (1996). The new positioning: The latest on the world's \# 1 business strategy. McGraw Hill, New York.

[135] Trout, J., \& Ries, A. (1972b). How to position your product. Advertising Age, 8, 114-16.

[136] Trout, J., \& Ries, A. L. (1972a). Positioning cuts through chaos in the marketplace. Advertising Age, 43, 51-54.

[137] Turban, D. B., \& Greening, D. W. (1997). Corporate social performance and organizational attractiveness to prospective employees. Academy of Management Journal, 40(3), $658-672$

[138] UNDP. (2006). Beyond Scarcity: Power, Poverty and the Global Water Crisis. Brussels: United Nations Development Programe.
[139] Visser, W. (2005). Corporate Citizenship in South Africa: A Review of Progress Since Democracy. Journal of Corporate Citizenship, 18, summer: 29-38.

[140] Visser, W. (2006). Corporate Social Responsibility in Developing Countries\| Retrieved from http://www.waynevisser.com/chapter_wvisser_csr_dev_cou ntries.pdf (accessed on April, 15, 2013, 3:20 pm)

[141] Walker, O.C., Boyd, H.W., \& Larreche, J.C. (1996). Marketing Strategy: Planning and Implementation, Irwin, Chicago, IL, 174-95.

[142] Wartick, S. L. and Rude R. E. (1986), Issues Management: Corporate Fad or Corporate Function?, California Management Review 29 (1), 124-132.

[143] WBCSD (1999). Corporate social responsibility. World Business Council for Sustainable Development, Geneva.

[144] Wood, D. J. (1991a), Social Issues in Management: Theory and Research in Corporate Social Performance, Journal of Management 17 (2), 383-406.

[145] Wood, D. J. (1991b), Corporate Social Performance Revisited, Academy of Management Review 16 (4), 691718.

[146] Worthington, S., \& Horne, S. (1993). Charity affinity credit cards-marketing synergy for both card issuers and charities. Journal of Marketing Management, 9, 301-313.

[147] Wyckham, R.G., Fitzroy, T., \& Mandry, G. D. (1975). Marketing services: an evaluation of the theory. European Journal of Marketing, 9 (1), 59-67.

[148] Young, M.R. (1993). Positioning of financial institutions using adaptive perceptual mapping and computer-aided interviewing. Journal of Professional Services Marketing, 9 (1), 159-71.

[149] Zeithaml, V.A., \& Bitner, M.J. (1996). Services Marketing. The McGraw-Hill Companies, New York, NY, 286-95.

[150]Zhuang, C., \& Wheale, P. (2004). Creating Sustainable Corporate Value: A Case Study of Stakeholder Relationship Management in China. Business and Society Review, 109(4), 507-47.

[151] Zulkifli, N., \& Amran, A. (2006). Realising corporate social responsibility in Malaysia: A view from the accounting profession. Journal of Corporate Citizenship, 24, 101-14.

[152] http://www.gipcghana.com/previous-gc-100-editions accessed March 11, 2013, 2:15pm

[153] http://www. airtelghana.com (Last visited on $12^{\text {th }}$ February, 2013, 1:30 pm)

[154] http://www. vodafoneghana.com (Last visited on $12^{\text {th }}$ February, 2013, 1: 45pm)

[155] http://www.ghanabizmedia.com/ghanabizmedia/july-2011bulletins/353-mtn-set-to-boost-its csr activities.pdf (accessed 15th May 2013, 1:15 pm)

[156] http://www.nca.org.gh/40/105/Market-Share-Statistics.htm $1,11^{\text {th }}$ April, 2014, 10: 27am

[157] http://www.ghanaweb.com/GhanaHomePage/NewsArchiv e/artikel.php?ID=133752, March 9, 2013, 10:00 am 